Received Date : 11-Aug-2015

Revised Date : 10-Aug-2016

Accepted Date : 01-Dec-2016

Article type : Original Manuscript

\title{
Children's Agency: 'getting by, getting back, getting out and getting organised' under welfare-to-work in Australia
}

One in four children in lone-parent households in Australia lives in poverty with their parents in low-paid employment or on income support (Wilkins, 2015). In seeking to reduce the number of lone-parents on income support successive Australian governments have moved to 'activation' policies in a welfare-to-work approach that now underpins most forms of income support for working age Australians (McDonald \& Marston, 2005). Recent shifts have seen lone-parents with children from eight years old moved over to Newstart Allowance (NSA), a programme designed for unemployed persons without dependents. The NSA benefit has been critiqued as insufficient to support families and as such a potential violation of children's rights (ACOSS, 2013a, 2013b).

Welfare-to-work policy in Australia has drawn strongly on the social inclusion agenda in which participation in paid work is a central objective (ASIB, 2011). In the case of lone-parents it is undergirded by a moralising discourse with 'welfare dependent' lone-parents regarded as poor role models for their children (Marston, 2008). Titterton (1992) argues that approaches that treat social groups such as lone-parents as homogenous 'problem groups' can overlook the diversity of life situations and the strategies and resources that individuals employ to cope with or improve their lives. He calls for a new 'welfare paradigm' focussing on how individuals use their agency to manage threats to their personal and social welfare (1992: 16-8). This article This is the author manuscript accepted for publication and has undergone full peer review but has not been through the copyediting, typesetting, pagination and proofreading process, which may lead to differences between this version and the Version of Record. Please cite this article as doi: $10.1111 /$ chso.12206

This article is protected by copyright. All rights reserved 
posits that such an approach holds value in understanding the agency and needs of children: as such, it is concerned less with the consequences of the welfare-to-work policy itself and more with children's expressions of agency in response to those consequences.

Research in Australia into the impacts of welfare-to-work policy has tended to focus on the perspectives of mothers' (Baxter \& Alexander, 2008; Baxter \& Chesters, 2011; Baxter \& Renda, 2011; Bodsworth, 2010). Until recently children have been regarded, even by researchers, as passive, subordinate, and incomplete: as future adults (Qvortrup, 1994; Wyness, 2012). Poor children are often further marginalised as a result of their perceived vulnerability. However, giving a voice to vulnerable children through research is an important step towards improving the conditions of their lives (Morris, Hegarty \& Humphreys, 2012: 125). Poor children often experience not only the impacts of poverty but also complex domestic lives, unsafe neighbourhoods, sub-standard schooling and limited options for out-of-school activities (Ridge, 2006; Skattebol, Saunders, Redmond, Bedford \& Cass, 2012). They have nevertheless, also been found to be agents in contributing to and shaping their lives and the lives of others. Research reveals children as workers, carers, counsellors and economic actors contributing to family and 'real' economies (Ridge, 2002; Zelizer, 1985: 209). This article seeks to reveal more about this agency and the ways in which children are actors within the context of their lives, acknowledging them as reliable informants and providing valuable knowledge to inform social policy (Mayall, 2008).

\section{The child-centred research}

The data is drawn from child-centred participatory research activities with twenty-six children from lone-parent families on NSA. The girls (n13) and boys (n13) were between eight and seventeen years old, although the majority where over twelve as the recent policy shifts had moved many families with older children on to NSA that had previously been on the more generous Parenting Payment. They were recruited as part of a wider study that included lone-parent families from suburban Melbourne and regional cities and rural towns in Victoria, reflecting significant geographical differences (Birrell, Rapson \& Hourigan, 2002). 
Enhancing the agency of the children was a central concern of the research methodology. A risk assessment was conducted with their mothers prior to the study to ensure that children were not put at any risk through an investigation about painful subjects that opened up fresh wounds (Boyden \& Ennew, 1997; Morris et al., 2012). The children received a plain language information sheet about the research and were asked to give 'assent' - agreement to participate that lies between no involvement in discussions and the full decisional authority of the parent. They were given the opportunity to co-sign if they wished (Spriggs, 2010: 19). Informed consent was only sought from the parent once the child had given assent. The child's right to withdraw at any stage was explained and the researcher was attentive to explicit as well as implicit signs that may have indicated the need to break or unwillingness to continue: for example yawning or distractedness (Morris et al., 2012: 131-2; Redmond, 2008: 19; Spriggs, 2010). Children were given the option to have their parents present during the research which was conducted in the family home and approximately an hour in duration.

The participatory activities selected allowed for a wide range of ages, abilities and literacy levels and provided an entry point for unstructured interviews about aspects of children's lives without relying on preconceived notions about what was important to them. The participatory activities, 'My Week' (Plate 1) and 'My Social Map' (Plate 2), invited children to show through their drawings various aspects of their daily lives: activities, the places they went and the people with whom they spent time (Boyden et al., 1997: 137-8; James \& Christensen, 2008: 158). The researcher sat alongside the child helping to minimise the power imbalance and the open interviews and follow-up questions flowed from the activities (Mayall, 2008; Punch, 2002). These were recorded and later transcribed and the drawings and social maps photographed. Pseudonyms are used to protect anonymity.

Plate 1: 'My week' -Seth (11yrs)

Plate 2: ‘My Social Map' Evie (9yrs)

\section{Children's Agency}

In seeking to develop a more nuanced understanding of children's roles as agents in shaping their own and their families lives, Lister's (2004) model of four forms of agency- getting by, getting out, getting back at, and getting organised provided a 
useful tool to analyse the data (Lister, 2004: 124-57). The four forms sit within two axes (see Figure 1): everyday/strategic and personal/political. The everydaystrategic axis refers to the actions an individual undertakes on a day to day basis or to improve their lives strategically over the longer term. This includes non-reflexive or instinctive actions as well as the reflexive and strategic aspects of agency. On the personal-political axis are actions aimed at improving one's own situation or those that seek to bring about broader social or political change (Lister, 2004: 129-30). In the findings that follow, getting by is the form of agency most empirically supported, sitting within the everyday-personal area where children are most able to express their agency. There is also evidence of children's actions, or at the very least their desire to act, in more strategic and public ways. The extent to which their socioeconomic circumstances impact on their capacity to act in these areas is also of interest.

Figure 1. Forms of Agency exercised by people in poverty

\section{Getting by}

Getting by sits within the personal/everyday quadrant and deals with the things individuals do to cope, keep going and get by. These can often be taken for granted or not seen as expressions of agency (Lister, 2004: 130). They include reflexive agency- involving rational choice and reflexive monitoring but also non-reflexive modes that are often impulsive responses to powerlessness (Hoggett, 2001: 53). Studies have found children employ a range of strategies to manage their family's economic adversity including saving or contributing their own money, going without food, clothes, and social activities and seeking support outside of the home (Attree, 2006; Skattebol et al., 2012). They also exercise their agency by excluding themselves from social situations that are likely to cost money or cause them embarrassment (Taylor \& Fraser, 2003) and mediate their own needs and wants so as to avoid having to ask for money and the disappointment of being told 'no' (Skattebol et al., 2012: 41-2).

In this study getting by was the strongest feature of children's lives. They went without things that would be considered normal for children their age like sporting 
and recreational activities, but also more basic needs like food and health care. Many of the children spoke about 'not really needing' things, suggesting they were actively moderating their own needs and adapting preferences around what their families could afford. They reported doing this so as not to place more stress on their mothers, and also as a strategy to avoid the disappointment of not being able to have things they wanted.

Like my birthdays in a week and I don't really need anything. There's no point in stretching the budget for a stupid little birthday present when you can get little chocolates for ten bucks or so...some of them just want too much and you just sort of see that it is not very necessary. You see the difference between what you need and what you want. ...sometimes it really hurts when you can't have things that you want (Karalee, 13).

Children were agents in managing household budgets and strategising, going without or delaying the purchase of items such as school shoes to save money. They were also active in reducing household expenditure on heating and electricity.

...extreme budgeting can be tough because if you are under budget by the end of the week we'll have about $\$ 4$ left and sometimes we can't buy milk...So you just have to wait until the pay comes in again and then its alright for a couple of days and then it just cycles over and by the end of the week... without a job it just doesn't last for the whole week. If we are careful we can make it last pretty well. But sometimes it just doesn't work. Like the extreme budgeting would be like trying to spend as little as possible. Like the power- trying to cut that out and the water and the gas and the phones and the internet it's all of that. (Mandy, 14)

Some children drew on the support of others and grandparents in particular helped out with financial and practical support. Children also garnered support from friends borrowing money, visiting them when they knew there was no food at home or to get away from the conditions of their own homes. This raises areas for further study about relationships of agency and dependency among peers.

I don't really want to ask for money for things, like if my friends are going out or doing something, I say I can't go, or I'm busy, cos I don't want to ask for the money to go out.

I sort of feel like all the time I am relying on my friends, like if they really want me to come they will offer to pay for me and I feel really bad about that...I don't want to be 
taking money from my friends sort of... so I feel like I am always depending on them. Sometimes I go to my friend's house, like if I know that we don't have enough food at home (Eliza, 16).

Several families had moved house since their mothers had been moved to NSA due to financial pressures and the fear of eviction and homelessness was a common theme. When families moved children had to adapt to new neighbourhoods and fit in at new schools. They also adapted to changing child-care situations if their mother was working: staying home alone when they were unwell, taking greater responsibility for self-management and care or spending time with new carers who were often not well known to them. Seth's mum worked in the city and often got held up.

Yeah, when she worked she used to take me to the after-school care but there was very bad boy there named Nathaniel... So I stopped doing it and started walking home ... if she's not at the gate I just go home...l'd go here but sometimes the door was locked so I would jump over the gate there and go through the back door, the doggy door was small enough for me... or the door is unlocked so I can just open the door, but that is a bit dangerous so we don't like doing that. I didn't like it but I had Toby [oog] to keep me company. (Seth, 11)

This example of how poor children's agency may be prompted by necessity rather than choice suggests non-reflexive (Hoggett, 2001) acceptance and adaptation as a common but perhaps overlooked form of agency.

\section{Getting (back) at}

Lister (2004) identifies getting (back) at as forms of resistance that could include expressions of anger, despair or forms of destructive agency against themselves, their families, or wider society (Lister, 2004: 140-1). For children getting back can be a response to their sense of powerlessness or a challenge to authority. Studies have found children play active roles in managing the complex reconstituted family structures that result from family breakdown (Pryor \& Trinder, 2004). For many of the children in this study their family was the site of expressions of resistance or anger- 
in particular towards father's who did not provide the financial support the children felt entitled to. Matilda's decision to break ties with her father was one example.

Well, it started off as fight and then he just made it into this big thing. He has a wife and his wife has an original daughter- she's fourteen. And then they had two other kids a girl and a boy... He tried to stop me doing dancing- he was never really into that and then they just have arguments with me and they just call me out of the blue...And then he informed me that the girls were doing dancing. I went 'it was alright for them to do dancing but it's not alright for me?' and he said 'that's different'...blah, blah....he's just crazy (Matilda, 12).

Matilda decided to get back at her father by severing their relationship. This expression of agency gave her some power but came with consequences as she and her mother moved house so her father could no longer make contact with her creating other issues around schooling and access to transport.

In a different expression of getting back, Leo had been caught smoking marijuana at school. When asked why he thought he did it he explained:

Well I feel like my mums.... well it's not my mums fault, it was my choice but I feel like my mum wasn't there because of [work]. Like she's trying to afford us and it's just that I wanted relief and there was all this talk about it and it sort of came about (Leo, $15)$.

Children have very few avenues in which to show resistance and school and home can become sites for their expressions of getting (back) at but as for both Matilda and Leo getting back can also come at a cost. Some older children were aware of the stigma attached to their poverty and family circumstances that had led to incidents of bullying and conflict at school.

It feels like society hates us, wants us not to exist, I feel like we've been chucked on the rubbish heap and everyone's OK with that (Eliza, 16).

The stigma attached to welfare and poverty was similarly expressed by many of the children and gives a sense of the potential damage to their self-esteem and identity (Lister, 2004: 118). The significance of shame and humiliation and 'narratives of personal failure' in maintaining social inequality is well understood (Beck, 2000: 167; Goffman, 1968) and was a pervasive theme of this study. The ways in which poverty 
and stigma can lead to acts of resistance that are potentially damaging for children is an area where further study would be valuable. Despite this many children spoke about their future plans to get out of their current situations.

\section{Getting out}

Getting out encompasses a range of 'officially sanctioned responses to poverty' such as education and employment. For children, getting out of their situations is rarely possible but many in this study were strategic and aspirational about how they might get out in the future. Many were in paid employment helping their families' to get by; contributing to food, rent and fuel. They also spoke of trying to save for things like moving away to university or getting their driver's licence and saw employment as advantageous to future work prospects. Some were in formal employment which placed added pressure on them to manage schooling and social activities around shifts that were often late at night or across weekends. The income that flowed from work seemed beneficial and necessary in the short term however, finding balance was often difficult.

It's so hard, ... I have work and I have sport and I have school and then when Caily was born, like my dad and his wife said to us, on the first day in hospital when she was born, you want to be making the effort to get to know her, if you want this relationship with her you need to make it work...but, trying to fit 5 minutes in to see her with everything else I'm doing it gets really hard. And my friends, I don't really have a social life. And then like the last three weeks of last term I was so sick. I was going in for my exams and I was like I can't walk. I worry about that all the time. I am like how am I going to get through year 12. I've considered not doing it and going to TAFE [Technical and Further Education] and starting something else. But then I don't really don't know what I want to do when I finish school so how can you start something if you don't know what you want to go. So I have to do Year 12 but then I wonder how I am going to do year 12 with everything else l'm doing to fit in at home. So you know, it just gets so busy and exams coming up, and I don't want to do any of it anymore (Kayla, 16).

Paid work for young people can have positive impacts when it is balanced with other areas of their lives, however, the 'activation' of children from families on income support into the adult world of work and care when it impacts negatively on 
schooling or social inclusion may act to increase structural constraints for them in the future (Redmond, 2010: 479).

Some children worked more informally in baby-sitting, busking, or helping out with household chores. Several of the older children were learning to drive and saw this as a way to relieve the pressure on their mothers and to improve their own mobility and employment prospects especially in rural and regional locations. For those living in rural and regional areas there were distinct barriers to higher education such as the cost of living away from home and some had already begun to plan how they could manage that.

I think [being poor] gives me less choices than what other people have because I can't afford to go to university like that's another thing l'll be saving up for and it's like in my mind just thinking that how am I going to afford it... If I apply for a job at IGA or something it's just I find it very frustrating with all the school hours I've got to do. $($ Leo, 15)

The interplay between social and cultural structures, future aspirations and the capacity individuals have to exercise agency was a common theme. When asked about her future study hopes Eliza explained how her lack of confidence in social situations and limited social connections might be an impediment to her succeeding in her desired career.

Your ability to sell yourself, to promote your work I guess...I'm confident in my artistic ability but l'm not so sure about talking to people who have more authority that me...it's a bit intimidating. (Eliza, 16)

Older children also looked to get out of their situation by going on income support themselves. Some received this directly which gave them a degree of independence and others had it paid to their mothers for family expenses. The implications of this early engagement with the welfare state is an area where further research would be beneficial and suggests some contradictions in a policy that seeks to reduce welfare dependence.

A number of the children placed high value on their participation in social and cultural activities such as sports, church groups and music lessons. These were regarded 
as being important socially and in some cases also as pathways for future aspirations which they were active in managing. Matilda (12) for example learned dancing and had hopes of being accepted into a vocational school and Sonia (16) studied music which she planned to continue at university. The decision to prioritise these activities often meant sacrificing other material things- even food.

Many of the children spoke about how important education was for getting out and Eliza's comments highlight how many children were socialised by their mother's preferences (Elder, 1974: 13).

It doesn't impact me that much because mum is...she believes that education is important so like if there is something we really need we will get that and we will eat like rice dishes and stuff for a week. She rathers us to have what we need. We can live off rice, it may not be as tasty or special but... its good (Eliza, 16).

As Lister (2004) notes, whilst 'individuals exercise their agency in negotiating routes out of poverty...the routes themselves are forged by structural and cultural factors which can assist or obstruct the exercise of that agency' (Lister, 2004: 145). The desire to 'get out' depends to a large degree on the aspirations and preferences that may be adapted to fit within an individual's economic circumstances (Redmond, 2008: 16).

For many children in this study the agency of getting out was expressed in terms of anticipated actions and hopes for the future. Whilst none were openly critical of their mothers, several of the girls spoke about not wanting to end up in the same situation. And also we know what husband to chose, yes, we know exactly who to marry. I will make sure my husband looks after me and doesn't beat me...we know because we have experienced it and have been the children of it. Not that mum intentionally did it and I don't hate her for it, I love her because she has tried so hard not to let that affect her. But I reckon I wouldn't want to make my kids live the way we do. I do like to be independent because I don't like to rely on people... because what if it all turns the table and turns you upside down and then you are lost and you might end up being a sole parent like mum did. It wouldn't be intentional for anybody but it just happens. And I don't want that to happen to me in the future or anyone really (Mandy, 14).

Several children spoke of imagined futures for themselves and their mothers and their hope for a 'way out' of the difficult circumstances of their day-to-day lives. Nine year old Evie showed a detailed drawing of a childcare centre she had planned 
where her mother could work and she and her friends could play. Seth also had future plans.

Well, mum and me always like dreamed of going around Australia in a little caravan RV thing like that ... if we sold the house we could actually do it. But we don't have enough money yet. When mum's fixed up the house. I would like it, I like travelling around. Ahh holidays! Well I think it is like buying a better house in a way. This house is not a very good house so maybe we could buy a better house or maybe rent an apartment that's dog friendly or something like that that could just help us a little bit, but the caravan thing is a good thing because I like travelling so that would be nice. And it would be a good experience for me and I would learn on the trip. So everyone would see benefits and my dog Toby he would love going in the outback and just searching around for stuff (Seth, 11).

These constructed futures suggest that forms of agency described as getting out may not necessarily be tied to action. By imagining positive futures for themselves children are using the resources and strategies they have available to them to cope and improve their lives.

\section{Getting organised}

Understanding the ways in which structural and cultural contexts can shape the collective strategic agency of the poor falls into the getting organised quadrant. This was the form of agency where the children in this study were least active. Lister argues that discourses that stigmatise and 'other' groups such as lone-parents can diminish their sense of political agency and capacity for activism (Lister, 2004: 149). For some families in this study children's sense of agency was diminished but there were also examples of resistance and families 'getting organised' despite the many obstacles they faced. Children may have limited scope for collective agency but many in this study spoke about feeling that they had rights that were being ignored and identified with others in the same circumstances. Leo and Seamus supported their mother in establishing a single-parent support group and appeared on a television current affairs show speaking about the impacts of the policy change. They also gave up some of their own family's scarce resources to help others.

....and sometimes the people that are living off soup every single week, my mum will just take $\$ 20$ off the house loan and just give it to them... Like its just really hard because she will discuss it and talk about it with the family...people are living in their cars and living off soup and we are living in a house that is paid for but it does really 
put stress on our family as well...knowing that we are the more fortunate ones I guess. (Seamus, 12)

Several children spoke about their participation in this research and felt that by speaking about their lives they could make some difference. Mandy and Sonia wanted to 'tell the politicians':

M: Can you please increase [Newstart] because it would make everybody's life so much better. It doesn't have to be like millions. A little bit...

S: Even a $\$ 100$ extra like that would be nice.

M: have you seen how parents react to money worries, have you seen how hard it can be when you want your mum to be happy but the bank is empty?

S: And also jobs are hard to get.

M: And if she was at jobs all the time then she wouldn't be our parent.

S: She wouldn't be there to help us.

M: We need our mother, or a father...we need love. We are going through high school. We come home from school with assignments on your hands and they can help you do them.

S: Help you cope, comfort, love, a wise role model to help you through stuff.

$\mathrm{S}$ : One of the reasons mum doesn't get jobs is because of the whole stereotype of the single-parent.

M: We've been knocked back for houses because she's a sole parent (Mandy, 14 and Sonia, 16).

The need for further research to provide avenues for children's voices to be heard about issues that affect them and to open up pathways for them to exercise their agency in more public and strategic ways was a key finding of this study.

\section{Discussion and implications for policy}

This article highlights the extent to which children are creative, autonomous and purposive actors across all of Lister's four types of agency but also how their agency can be constrained by structural circumstances. It was in managing the everydaygetting by- that children were most active and often at considerable personal cost. In many cases the impacts of the welfare-to-work policy and their families' disadvantage resulted in children being 'activated' into adult roles as workers, carers, counsellors and managers of household budgets. Whilst these experiences were 
not necessarily seen as negative, many of the children in this study spoke about feeling stressed and that balancing these things compromised other areas of their lives particularly schooling and social relationships. The findings suggest that although children are generally regarded in policy as dependent and a cost burden they are also part of the 'real' economy (Zelizer, 1985), contributing to their families' resources and incurring costs to themselves. It indicates a contradiction in policies that seek to address disadvantage by 'activating' parents to paid work but in doing so hasten the 'activation' of children, potentially adding to structural constraints in their future. The active participation in work and future aspirations of many of the children also suggests a weakness in policy that seeks to activate lone-parents in to paid work so as to provide children with role models of work ethic and prevent intergenerational welfare dependence (Blaxland, 2009).

The avenues available to children for getting (back) at in this study were limited. Many children blamed their financial circumstances on their fathers' lack of support as much as the policy or their mothers' situation and this often became a site of tension for older children in particular. Whilst issues about child support were not a focus of this study, children are playing active roles in negotiating the often difficult family relationships and financial arrangements resulting from family breakdown and this is an area where further research would be valuable.

Although many of the children spoke about plans for their future, their ability to get out in the short term was limited. The financial benefits of their efforts to get out through work were often subsumed by their families' immediate needs. Many of the children recognised education as a pathway to get out but there were barriers for them with lack of economic resources placing constraints on current and future plans for education. Geographical location was also a key issue as for children in rural and regional areas, getting out often also meant moving to the city for more opportunities in education and employment. The findings suggest that welfare models that are sensitive to children's social, economic and personal resources and how they restrict or support their agency may lead to better policy directions.

Finally, the scope for children in getting organised is limited by their relative lack of political power and further research which makes a space for their voices to be heard and shines a light on their agency and contributions but also the costs they incur will 
be valuable. A way forward in the design of better policy necessitates a move away from thinking about homogenous 'problem groups' such lone-parents towards a broader conception of families as units of interdependent individuals with diverse, changing and particular needs. Policy which supports the agency and well-being of all family members and removes the stigmatising discourses associated with 'problem groups' provides the challenge for policy-makers of the future.

\section{Bibliography}

ACOSS 2013a, 'Reduce Poverty:child poverty and family payments ', viewed 18.06.2015, <http://acoss.org.au/images/uploads/Reducing_poverty_ACOSS_2013_electi on_factsheet.pdf>.

--- 2013b, 'UN asks Australian Government to explain violation of single parents' rights', viewed 25.6.2015, <http://wWw.acoss.org.au/media_release/un_asks_australian_government_to _explain_violation_of_single_parents_rights/>.

ASIB 2011, 'Addressing barriers for jobless families', viewed 18.06.2015, $<$ http://communitydoor.org.au/sites/default/files/Addressing\%20barriers\%20for \%20jobless\%20families.pdf>.

Attree, P 2006, 'The social costs of child poverty: a systematic review of qualitative evidence', Children and Society, vol. 20, no. 1, 54-66.

Baxter, J \& Alexander, M 2008, 'Mothers' work-to-family strain in Single and Couple parent families: the role of job characterisitcs and supports', Australian Journal of Social Issues, vol. 43, no. Winter, 195-214.

Baxter, J \& Chesters, J 2011, 'Perceptions of work-family balance: how effective are family-friendly policies?', Australian Journal of Labour Economics, vol. 14, no. 2, 139-51.

Baxter, J \& Renda, J 2011, 'Lone and couple mothers in the Australian Labour Market: Differences in Employment Traditions', Australian Journal of Labour Economics, vol. 14, no. 2, 103-22.

Beck, U 2000, 'Living your own life in a runaway world: individualisaton, globalisation and politics', in W Hutton \& A Giddens (eds), On the Edge: Living with global capitalism, Jonathan Cape, London. 
Birrell, B, Rapson, V \& Hourigan, C 2002, 'The origin of Lone-parent concentrations in metropolitan and regional Australia', Family Matters, vol. 62, no. Winter, 117.

Blaxland, M 2009, 'Everyday negotiations for care and autonomy in the world of welfare-to-work: The policy experience of Australian mothers, 2003-2006', University of Sydney, Sydney.

Bodsworth, E 2010, Making Work Pay, context, Brotherhood of St Laurence, Fitzroy, Victoria.

Boyden, J\& Ennew, J (eds) 1997, Children in Focus: a manual for participatory research with children, Save the Children Sweden, Stockholm.

Elder, JGH 1974, Children of the Great Depression, The University of Chicago Press, London.

Goffman, E 1968, Stigma, Prentice-Hall, Englewood Cliffs, NJ.

Hoggett, P 2001, 'Agency, rationality and social policy', Journal of Social Policy, vol. 30, no. 1, 37-56.

James, A \& Christensen, P (eds) 2008, Researching with Children: Paradigms and Perspectives, 2nd edn, Routledge, Oxon.

Lister, R 2004, Poverty, Polity Press, Cambridge.

Marston, G 2008, 'A war on the poor: constructing welfare and work in the twentyfirst century', Critical Discourse Studies, vol. 5, no. 4, 359-70.

Mayall, B 2008, 'Conversations with children:working with generational issues', in A James \& P Christensen (eds), Researching with Children: perspectives and paradigms, Routledge, London.

McDonald, C \& Marston, G 2005, 'Workfare as welfare: governing unemployment in the advanced liberal state', Critical Social Policy, vol. 25, no. 3, 374-401.

Morris, A, Hegarty, K \& Humphreys, C 2012, 'Ethical and safe: research with children about domestic violence', Research Ethics, vol. 8, 125-39.

Pryor, J \& Trinder, L 2004, 'Children, families and divorce', in J Scott, J Treas \& M Richards (eds), The Blackwell Companion to the Sociology of Families, Blackwell, Malden, MA.

Punch, S 2002, 'Research with children: the same or different from research with adults?', Childhood, vol. 9, no. 3, 321-41.

Qvortrup, J (ed.) 1994, Childhood Matters: An Introduction, Avebury, Aldershot, UK. 
Redmond, G 2008, Children's Perspectives on Economic Adversity: A review of the literature, no. 149, University of NSW, Sydney.

Redmond, G 2010, 'Children's agency and the welfare state: Policy priorities and contradictions', Childhood, vol. 17, no. 4, 470-84.

Ridge, T 2002, Childhood Poverty and Social Exclusion: from a child's perspectives, The Policy Press, Bristol.

--- 2006, 'Childhood Poverty: a barrier to social participation and inclusion', in E Kay, et al. (eds), Children, Young People and Social Inclusion, The Policy Press, Bristol.

Skattebol, J, Saunders, P, Redmond, G, Bedford, M \& Cass, B 2012, Making a Difference: Building on Young people's experiences of economic adverisity (Final Report), University of NSW, Sydney.

Spriggs, M 2010, Understanding Consent in Researching with Children: The Ethical Issues, University of Melbourne, Murdoch Children's Research Institute, Royal Childrens Hospital, Melbourne

Taylor, J \& Fraser, A 2003, Eleven Plus: Life chances \& family income, Brotherhood of St Laurence, Melbourne, 230.

Titterton, $M$ 1992, 'Managing threats to welfare: the search for a new paradigm of welfare', Journal of Social Policy, vol. 21, no. 1, 1-23.

Wilkins, R 2015, 'Families, Incomes and Jobs', HILDA, vol. 9.

Wyness, M 2012, Childhood and Society, Palgrave MacMillan, Houndmills, Basingstoke, Hampshire.

Zelizer, VA 1985, Pricing the Priceless Child: The Changing Social Value of Children Basic Books, New York. 

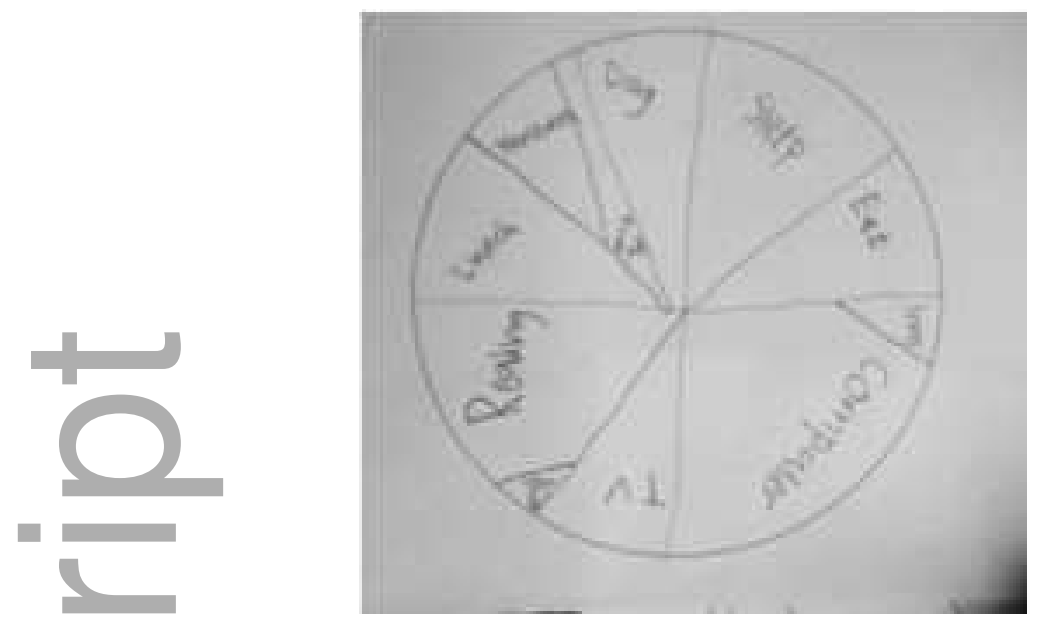

chso_12206_f1.jpg
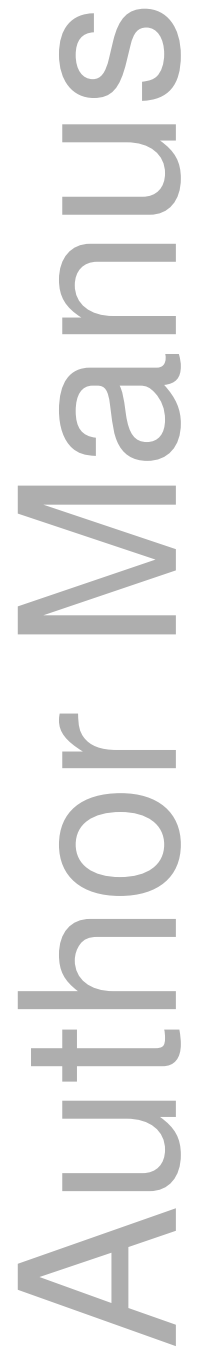

This article is protected by copyright. All rights reserved 


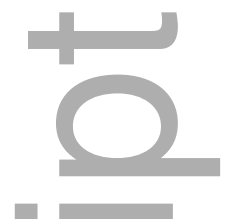

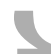
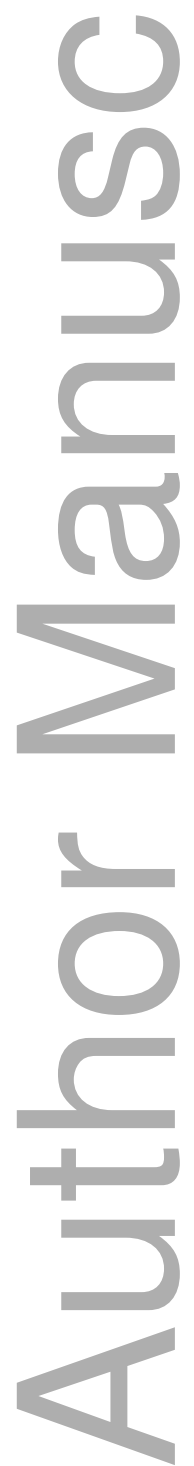

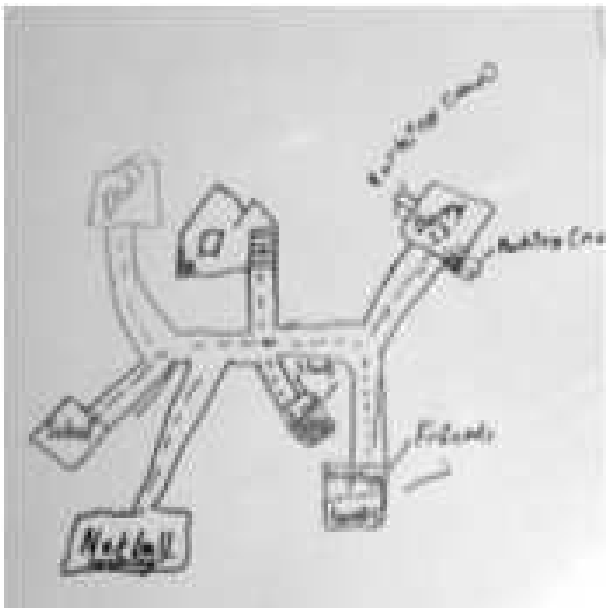

chso_12206_f2.jpg 


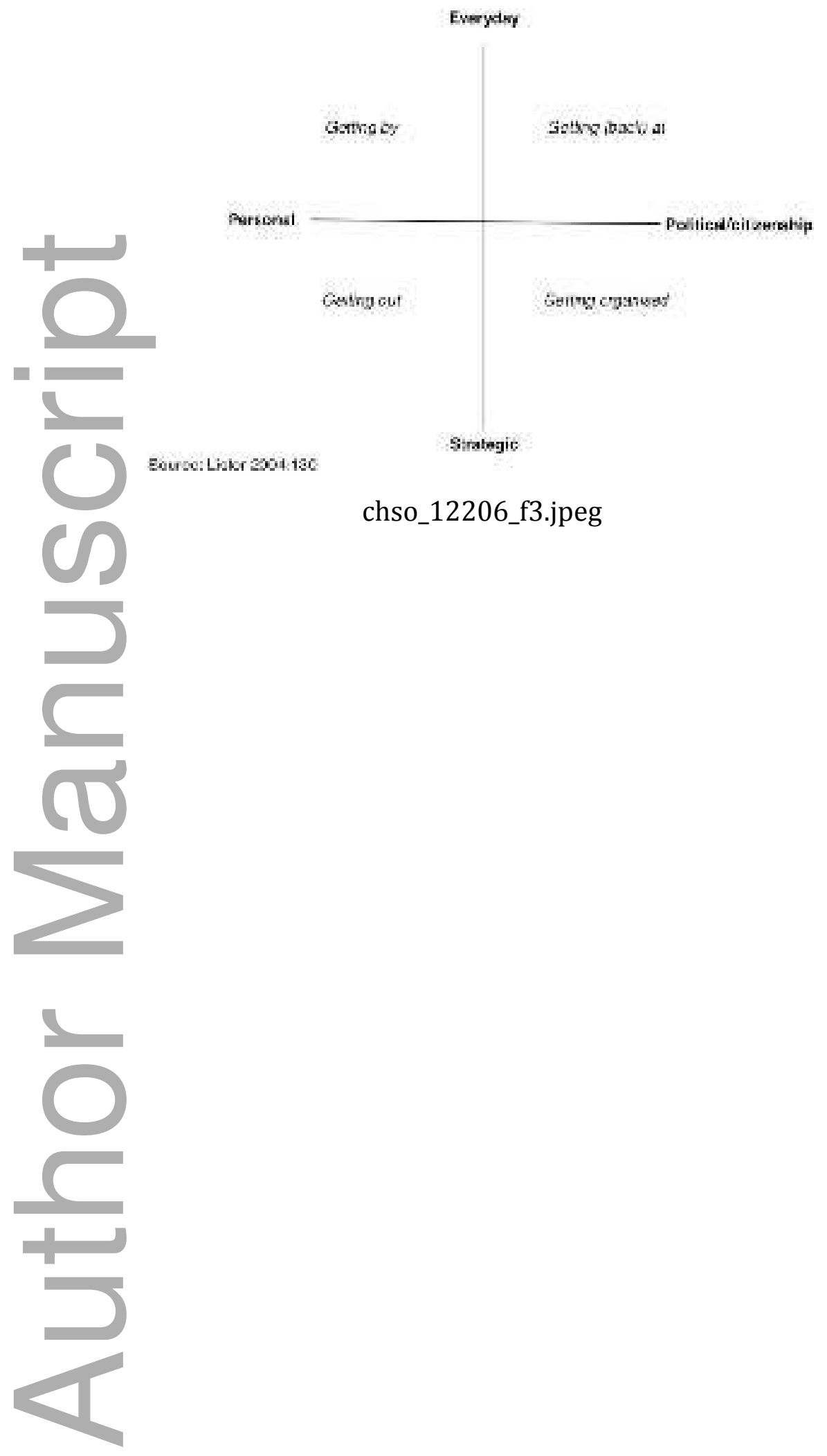

This article is protected by copyright. All rights reserved 


\section{University Library}

\section{- M M I N E R VA A gateway to Melbourne's research publications}

Minerva Access is the Institutional Repository of The University of Melbourne

Author/s:

Podesta, J

Title:

Children's Agency: 'Getting By, Getting Back, Getting Out and Getting Organised' Under Welfare-to-Work in Australia

Date:

2017-09-01

Citation:

Podesta, J. (2017). Children's Agency: 'Getting By, Getting Back, Getting Out and Getting Organised' Under Welfare-to-Work in Australia. CHILDREN \& SOCIETY, 31 (5), pp.353-364. https://doi.org/10.1111/chso.12206.

Persistent Link:

http://hdl.handle.net/11343/292497 